\title{
What is the Contribution of Local Original Revenue to Regional Financial Independent?
}

\author{
Purnama Sari ${ }^{\mathrm{a}}$, R.Rindu Garvera ${ }^{\mathrm{b}}$, Aan Anwar Sihabudin ${ }^{\mathrm{c}} *$ \\ ${ }^{a b c}$ Galuh University, Ciamis, West Java, Indonesia
}

\section{ARTICLE INFORMATION ABSTRACT}

\section{Article history:}

Data submission : 02 November 2017

$1^{\text {st }}$ revision: 10 February 2018

Accepted: 16 December 2018

Available online: 30 December 2018

Keywords: local original revenue, regional financial independence, decentralization, regional autonomy

\begin{abstract}
As a manifestation of decentralization, the purpose of local original revenue is to give authority to local governments to fund the implementation of regional autonomy in accordance with regional potential. With the regional autonomy policy, all regions are expected to be able to maximize their financial capabilities so that they can fund all government affairs in the regions independently. The purpose of this study was to analyze the contribution of local original revenue to regional financial independence. The research method used is a descriptive method with a quantitative approach, where the research was conducted on the Regional Financial Management Agency of Ciamis Regency. Even in this study will compare the results of research conducted in several other regions in Indonesia as well as in several regions in other countries. The results showed that the contribution of regional local revenue to regional financial independence in Indonesia was still low. The same conditions in several countries in Africa and Europe, where regions are still dependent on funds transferred from the central government, to carry out development and services to other publics.
\end{abstract}

2018 FIA UB. All rights reserved.

\section{Introduction}

Based on the Republic of Indonesia Law Number 23 of 2014 concerning local government, regions are given the opportunity to be independent in regulating and managing the course of the government wheels by exploring and utilizing existing economic resources for the welfare and prosperity of the people in the region. Siregar \& Pratiwi (2017) explained that the financial capacity of an area can be seen in the size of local original revenue. Local original revenue is considered as one indicator to measure regional financial independence.

In determining the success of the regional autonomy policy, it does not only concern the transfer of authority from top to bottom but also needs to be realized on the basis of initiatives from below to encourage the growth of the independence of the regional government itself. In the paternalistic culture of Indonesian society, decentralization and regional autonomy policies will not succeed if they are not balanced by conscious efforts to build their own regional self-reliance and independence.

Decentralization, or decentralization of government, refers to the restructuring or reorganization of authority so that there is a system of joint responsibility between government institutions at the central, regional and local levels in accordance with the principles of subsidiarity (UNDP in Rusyiana, 2017). To support the implementation of regional autonomy, it requires proportional broad, real and accountable authority in the regions which is realized by regulating, distributing, and utilizing fair national resources, as well as the financial balance of the central government and regional governments.

With the existence of regional autonomy policy, it is expected that all regions in Indonesia, including Ciamis Regency, are able to carry out all government and development affairs by relying on regional local original revenues extracted from within the region concerned. After the release of Pangandaran Subdistrict from Ciamis Regency, it caused a reduction in local original revenue of around 12 billion rupiahs per year. This is very influential on regional financial independence because all this time Pangandaran District has become the biggest contributor to local original revenue for Ciamis Regency which originates from the tourism sector. 
This study aims to analyze the contribution of local original revenue to regional financial independence. In this study also will compare the results of research conducted in other regions in Indonesia as well as in several regions in other countries.

\section{Theory}

Based on the Law of the Republic of Indonesia Number 33 of 2004 the local original revenue is the income obtained by the region and collected based on the prevailing laws and regulations. Local original revenue aims to give authority to local governments to fund the implementation of regional autonomy in accordance with the regional potential as a manifestation of decentralization.

Several benefits of decentralization are transparency of information for the public in the region, increasing accountability because public services are closer, decision making is carried out by local governments, improving fiscal management, increasing economic growth and market security (Sujarwoto, 2017). One of these advantages is that the local government has the authority to manage finances independently, one of which is to explore all available resources in the region to increase revenues derived from local original revenues.

In the Law of the Republic of Indonesia Number 23 of 2014 in lieu of Law Number 33 of 2004 challenging the regional government, it is stated that the sources of local original revenue come from local taxes, regional retributions, the results of the management of regional wealth and other local original revenue. These sources can be explored and optimized by local governments to be able to increase their revenues, to finance development in the region and improve the quality of services to the public.

One of the reasons for the implementation of regional autonomy is to provide opportunities for regions to get more money and freedom to manage finances independently. In its implementation, the regional government is required to have greater financial independence. The level of regional financial independence can be done by increasing the realization of regional revenues, which come from local original revenue (Ruliana, 2015).

\section{Research Method}

The research method used is a descriptive method with a quantitative approach. The purpose of using the method is to describe the phenomenon or characteristics of the data during the research and to test and answer the research questions.

The study was conducted at the Regional Financial Management Agency of Ciamis Regency as an institution that carries out financial management in the region. The focus of this study was to analyze how the contribution of local original revenue to the financial independence of the district of Ciamis. In this study also will compare the results of research conducted in other regions in Indonesia and in several regions in other countries.
To find out the contribution of local original revenue to regional financial independence, it will first be measured how the effectiveness of local original revenue and the level of regional financial independence are carried out on the regional income structure of Ciamis Regency.

The effectiveness of local original revenue is measured using the following formula:

Realization of sources acceptance

Effectiveness ratio of

local original revenue

$$
\begin{aligned}
& =\frac{\text { the local original revenue }}{\text { The target of sources acceptance }} \\
& \text { the local original revenue }
\end{aligned}
$$

The formula is used to measure the ability of local governments to realize local original revenues from those targeted. The ability to realize local original revenue is said to be effective if this ratio reaches at least from $1 \%$ to $100 \%$.

The formula is used to measure the ability of local governments to realize local original revenues from those targeted. The ability to realize local original revenue is said to be effective if this ratio reaches at least from $1 \%$ to $100 \%$.

Table 1. Financial Effectiveness Autonomous Region

\begin{tabular}{cc}
\hline Percentage $(\%)$ & Criteria \\
\hline$>100$ & Very effective \\
$90-100$ & Effective \\
$80-90$ & Quite effective \\
$60-80$ & Less effective \\
$<60$ & Ineffective \\
\hline
\end{tabular}

Meanwhile, the level of regional financial independence can be measured using the following formula:

$$
\begin{gathered}
\text { Level } \\
\text { of independence }
\end{gathered} \quad=\frac{\text { Realization of local original revenue }}{\text { Realization total revenue }}
$$

The level of regional financial independence can be seen in the following table:

Table 2. Relationship Patterns Level Independence

\begin{tabular}{cc}
\hline Financial Capability & Level of Independence $(\%)$ \\
\hline Very Low & $0-25$ \\
Low & $25-50$ \\
Medium & $50-75$ \\
High & $75-100$ \\
\hline
\end{tabular}

\section{Results and Discussion}

Based on Ciamis Regency's local original revenue realization data, it shows that in the 2012-2014 fiscal year it experienced an increase, but experienced a decline in 2015 and increased again in the 2016 fiscal year. Local original revenue derived from local taxes, regional retributions, the share of profits from regionalowned companies and other legitimate local original 
revenues as the largest revenue reaching $488,755.53$ million rupiahs.

The following is a table of Ciamis Regency's local original revenue realization data for the 2012-2016 fiscal year:

Table 3 Realization of Local Original Revenue for the 2012-2016 Fiscal Year (millions of rupiah)

\begin{tabular}{|c|c|c|c|c|c|}
\hline \multirow[b]{2}{*}{ Year } & \multicolumn{4}{|c|}{ Sources of Local Original Revenue } & \multirow[b]{2}{*}{$\begin{array}{c}\text { Total Local } \\
\text { Original Revenue }\end{array}$} \\
\hline & Local Tax & $\begin{array}{c}\text { Regional } \\
\text { Retribution }\end{array}$ & $\begin{array}{l}\text { The Share of Profits } \\
\text { from Regional- } \\
\text { Owned Companies }\end{array}$ & $\begin{array}{c}\text { Other Legitimate } \\
\text { Local Original } \\
\text { Revenue }\end{array}$ & \\
\hline 2012 & $17.718,41$ & $18.571,60$ & $2.486,03$ & $48.935,82$ & $87.711,86$ \\
\hline 2013 & $28.824,96$ & $22.920,80$ & $2.840,89$ & $62.889,26$ & $117.475,91$ \\
\hline 2014 & $42.117,03$ & $9.489,64$ & $3.318,03$ & $127.395,51$ & $182.320,21$ \\
\hline 2015 & $45.367,52$ & $13.251,35$ & $3.154,72$ & $118.531,33$ & $180.304,92$ \\
\hline 2016 & $54.483,34$ & $15.770,60$ & $3.501,87$ & $131.003,61$ & $204.759,42$ \\
\hline Amount & $188.511,26$ & $80.003,99$ & $15.301,54$ & $488.755,53$ & $772.572,32$ \\
\hline
\end{tabular}

The following is an analysis of the effectiveness of Ciamis Regency's local original revenues during the 2012-2016 fiscal year:

Table 4. Effectiveness of Regional Original Income for the 20122016 Fiscal Year (millions of rupiah)

\begin{tabular}{|l|c|c|c|c|c|}
\hline \multicolumn{1}{|c|}{ Year } & 2012 & 2013 & 2014 & 2015 & 2016 \\
\hline $\begin{array}{l}\text { Realization of Local Original } \\
\text { Revenue }\end{array}$ & $87.711,86$ & $117.475,91$ & $182.320,21$ & $180.304,92$ & $204.759,42$ \\
\hline Local Original Revenue Target & $81.717,49$ & $107.195,18$ & $161.636,56$ & $182.159,89$ & $196.976,94$ \\
\hline $\begin{array}{l}\text { Ratio of Effectiveness of Local } \\
\text { Original Revenue (\%) }\end{array}$ & 107,34 & 109,59 & 112,80 & 98,98 & 103,95 \\
\hline \multicolumn{1}{|c|}{ Criteria } & $\begin{array}{c}\text { Very } \\
\text { Effective }\end{array}$ & $\begin{array}{c}\text { Very } \\
\text { Effective }\end{array}$ & $\begin{array}{c}\text { Very } \\
\text { Effective }\end{array}$ & Effective & $\begin{array}{c}\text { Very } \\
\text { Effective }\end{array}$ \\
\hline
\end{tabular}

Table 4 shows that during the 2012-2016 fiscal year experienced a positive trend. Overall, almost during the fiscal year, the criteria were very effective because the results were $>100 \%$, and only in 2015 were effective criteria because the results were $90 \%-100 \%$ (Table 4).

All Ciamis regency revenues come from local original revenues plus balance funds originating from the central government, as well as other legitimate income. The level of regional financial independence is measured by comparing local original revenue with total regional revenues. The following is an analysis of the level of regional financial independence for the 20122016 fiscal year:

Table 5. Level of Regional Financial Independence 2012-2016 Fiscal Year(millions of rupiah)

\begin{tabular}{|c|c|c|c|c|c|}
\hline Year & 2012 & 2013 & 2014 & 2015 & 2016 \\
\hline Local Original Revenue & $87.711,86$ & $117.475,91$ & $182.320,21$ & $180.304,92$ & $204.759,42$ \\
\hline Balancing Fund & $1.353 .385,82$ & $1.494 .016,55$ & $1.270 .347,10$ & $1.342 .252,39$ & $1.413 .397,71$ \\
\hline Other Legitimate Income & $426.237,86$ & $585.001,44$ & $553.008,31$ & $769.997,05$ & $754.697,06$ \\
\hline Total Regional Income & $1.867 .335,54$ & $2.196 .493,90$ & $2.005 .675,62$ & $2.292 .554,36$ & $2.372 .854,19$ \\
\hline Level of Regional Financial Independence (\%) & 4,70 & 5,35 & 9,09 & 7,86 & 8,63 \\
\hline Financial Capability & Very Low & Very Low & Very Low & Very Low & Very Low \\
\hline
\end{tabular}

Table 5 depicts Ciamis Regency's regional finances during the 2012-2016 fiscal year were still dependent on balancing funds originating from the central government. This condition can be seen from the results of the analysis which shows that the level of regional financial independence gets a very low predicate because the results obtained are $0 \%-25 \%$.

This condition is due to the fact that the amount of local revenue is still much smaller than the balance funds and other legal income. Of the total regional revenues, the contribution of local revenue is just under $10 \%$. Although the condition of Ciamis Regency's regional financial independence is still very low, regional financial independence has increased in the 2012 to 2014 budget year. In the 2015 budget year, regional financial independence experienced a decline, and again experienced an increase in the 2016 fiscal year.

The contribution of local revenue to the total regional revenue of Ciamis Regency during the 2012-2016 fiscal year can be seen in the following figure 1 :

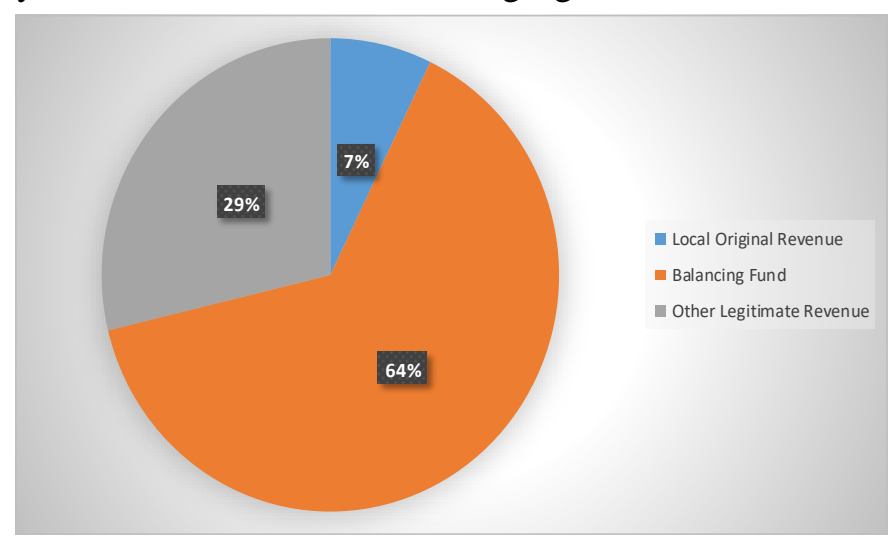

Figure 1. Regional Income for the 2012-2016 Fiscal Year

Figure 1 shows that during the 2012-2016 fiscal year the contribution of local original revenue was only $7 \%$. Meanwhile, the balancing fund from the central government has a contribution of $29 \%$, while the largest contribution comes from other legal income, which is $64 \%$. So it can be concluded that the contribution of local original revenue to the financial independence of the district of Ciamis is still very low.

Several studies conducted in several other regions in Indonesia showed the same results, as the results of research conducted by Ruliana (2015) showed that the provincial government of East Kalimantan during the 2009-2013 fiscal year had succeeded in increasing local original revenue. This condition has reduced the level of dependence of the regional government on the central government. The ability of the local government to collect local regional revenue is $39.68 \%$ of the total revenues, while the rest still comes from central government transfer funds. This condition explains that the level of regional financial independence is still low.

The results of research conducted by Fafurida \& Pratiwi (2017) show that financial independence tends to increase in all regencies/ cities in Central Java, but is still in the low category. This condition is caused by the local government being able to increase the amount of local original revenue from year to year. Based on the results of the analysis, the Semarang and Tegal regions have a lower financial dependency with a pattern of consultative relationships compared to other regions that have a higher level of dependence with an instructive relationship pattern.

Local sources of revenue consisting of local taxes, regional retribution, results of management of regional assets and other legitimate local revenue can affect the level of regional financial independence. Research conducted in the city of Bandung, one of the areas of West Java, showed the results that the local original revenue significantly affected the level of regional financial independence. Regional financial 
independence of the City of Bandung for the 2009-2013 fiscal year is at a low level (Erawati \& Suzan, 2015).

Several studies conducted in several countries in Africa show similarities and differences regarding research results. Grant funds provided by the central government in Ghana have resulted in reduced enthusiasm to raise internal funds by the regional government, compared to encouraging an increase in Internally Generated Revenues and Funds (IGF) (Mogues \& Benin, 2012). In Tanzania based on quarterly fiscal data shows that grant funds from the central government can increase income mobilization in the regions, especially in rural areas (Masaki, 2018). Local income mobilized by most local government authorities in Africa is indispensable, but not enough to develop and provide adequate public services for populations that are growing faster in Africa (Fjeldstad \& Heggstad, 2012).

Research in several countries in Europe shows the same results as this study. Observations made in Israel in the 1999 to 2009 budget year indicate that the dependence of regional governments on transfer funds from the central government is still high (Baskaran, Brender, Blesse, \& Reingewertz, 2016). Meanwhile, in Poland, the pattern of regional financial independence is very limited by the rules of the central government. Restrictions are made on the amount of regional income and freedom in using available funds. As a result, the local government cannot maximize the sources of local original revenue, so it can be concluded that the level of regional financial independence is still low (Kotarba \& Kołomycew, 2014).

The high level of regional financial independence is very necessary for regions in any country because regional financial independence shows the ability of regions to finance development and services to other public independently due to the decentralization policy issued by the central government. The ability of local governments to collect the amount of local original revenue is a major factor in measuring the level of regional financial independence. For this reason, the regional government must be able to optimize the sources of its own local regional revenue, so that the level of regional financial independence will increase.

\section{Conclusion}

This study concludes that the contribution of local original revenue to regional financial independence in Indonesia is still low. This condition is caused by the balance of funds from the central government is much greater than the amount of local original revenue that can be collected by several regions in Indonesia. The same conditions in several countries in Africa and Europe, where regions are still dependent on funds transferred from the central government, to carry out development and services to other publics.

\section{References}

Baskaran, T., Brender, A., Blesse, S., \& Reingewertz, Y. (2016). Revenue Decentralization, Central Oversight, and The Political Budget Cycle: Evidence from Israel. European Journal of Political Economy, Vol. 42, pp.1-16.
Erawati, N. T., \& Suzan, L. (2015). Pengaruh Pendapatan Asli Daerah Terhadap Tingkat Kemandirian Keuangan Daerah Kota Bandung (Studi Kasus Pada DPKAD Kota Bandung Periode 2009-2013). E-Proceeding of Management, Vol. 2(3), pp.3259-3266.

Fafurida, F., \& Pratiwi, E. N. (2017). Financial Independence of Regencies and Cities in Central Java. Economic Journal of Emerging Markets, Vol. 9(2), pp.199-209.

Fjeldstad, O., \& Heggstad, K. (2012). Local Government Revenue Mobilization in Anglophone Africa, CMI Working Paper. CMI (CHRMichelsen Institute), Bergen, Norway.

Kotarba, B., \& Kołomycew, A. (2014). Financial Independence of Local Government Units in Poland. Journal of Universal Excellence, Vol. 3(4), pp.101-104.

Masaki, T. (2018). The Impact of Intergovernmental Transfers on Local Revenue Generation in SubSaharan Africa: Evidence from Tanzania. World Development, Vol. 106, pp.173-186.

Mogues, T., \& Benin, S. (2012). Do External Grants to District Governments Discourage Own Revenue Generation? A Look at Local Public Finance Dynamics in Ghana. World Development, Vol. 40(5), pp.1054-1067.

Ruliana, T. (2015). Revenue Independence of East Kalimantan Province, Indonesian. Journal of Asian Scientific Research, Vol.5(7), pp.340-348.

Rusyiana, A. (2017). Does Decentralization Good for Reducing Communal Conflict? A Multilevel Analysis of Communal Conflict at Indonesia's Villages 2008 -2014. Journal of Public Administration Studies, Vol.1(3), pp.25-43.

Siregar, B., \& Pratiwi, N. (2017). The Effect of Local Government Characteristics and Financial Independence on Economic Growth and Human Development Index in Indonesia. Jurnal Manaiemen Dan Kewirausahaan, Vol.19(2), pp.65-71.

Sujarwoto, S. (2017). Why Decentralization Works and Does Not Work? A Systematic Literatur Review. Journal of Public Administration Studies, Vol.1(3), pp.1-10. 